\title{
Biochemistry, Not Oncogenes, may Demystify and Defeat Cancer
}

\author{
by Jay Kulsh [1]
}

\begin{abstract}
Presence of mutated genes strongly correlates with incidence of cancer. Decades of research, however, has not yielded any specific causative gene or set of genes for the vast majority of cancers. The Cancer Genome Atlas program was supposed to provide clarity but it only gave much more data without any accompanying insight into how the disease begins and progresses. It may be time to notice that epidemiological studies consistently show that the environment, not genes, has the principal role in causing cancer. Since carcinogenic chemicals in our food, drink, air and water are the primary culprit, we need to look at the biochemistry of cancer, with focus on enzymes which carry out any and all transformations in a cell. In particular, attention should be paid to the rate-limiting enzyme in DNA synthesis, ribonucleotide reductase (RnR) which is tightly linked to tumor growth. Beside the circumstantial evidence that cancer is induced at its vulnerable active-site by various carcinogens, there exists experimental proof of its role in initiating retinoblastoma and HPV-related cervical cancers. Blocking the activity of RnR is a certain way to arrest cancer.
\end{abstract}

Keywords: cancer; DNA sequencing; DNA synthesis; enzyme; free-radicals; genome; HPV; oncogenes; retinoblastoma; ribonucleotide reductase; RnR; SMT; TCGA

In 2005, at the onset of The Cancer Genome Atlas (TCGA) program, Dr. Eric C. Lander, director of Broad Institute of MIT and Harvard, declared in New York Times, "Knowing the defects of the cancer cell points you to the Achilles' heel of tumors." 1

At Cancer World 2013, Nobel laureate James Watson opined, "We can carry on and sequence every piece of DNA that ever existed, but I don't think we will find any Achilles heels [of cancer]."2

\section{Cancer war not won}

The current year 2021 is the $50^{\text {th }}$ anniversary of declaration of the 'war on cancer' by US President Nixon. He was inspired by President Kennedy's declared goal in 1961 to land a man on the Moon by the end of the decade -- which had come true, to international acclaim. However, the progress in the field of cancer has been quite limited despite plentiful funding over the five decades.

[1] Independent scientist; 2466 Parade Avenue, Simi Valley, CA 93063, USA; jkulsh@gmail.com; https://orcid.org/0000-0002-0906-5180 
Overall survival rates have improved, to varying degrees, for all cancers, primarily due to early detection and intervention. Preventative measures like reduced use of tobacco products have also shrunk the incidences of lung cancers. ${ }^{3}$ But an effective treatment is still out of reach for most cancers.

Common reasons given for this slow progress is that cancer is a very complex disease -- and that it may not be one but many diseases. However, there is another possibility, raised as early as 1994 by Scientific American magazine: "Have the researchers and clinicians been barking up the wrong trees...?"4

From the current perspective, the 'wrong trees' referenced in the statement, would all be generelated, since the vast majority of cancer research, during the last five decades, has been focused on the genetic aspect of the disease cancer. Could this approach, this emphasis on genes, be wrong to understand and tackle cancer?

There is growing evidence that this in fact may be the case. The close correlation between mutagenesis and cancer may not be causative in nature. Mutated genes may simply be a consequence of carcinogenesis, initiated elsewhere upstream. If so, then the genes-centered thinking may be hampering the researchers in their fight against cancer? The following few sections explore this possibility.

\section{Essence of gene-centric view of cancer}

Per prevailing genetic model, cancer is caused by mutation of genes, which are either inherited or acquired.

- An 'Inherited Gene Mutation' is present in the egg or sperm cell of the parents. In rare instances, post-zygotic de novo mutation can occur during early embryonic development. Such germline mutation is in every cell and so may be passed on to the next generation.

- An 'Acquired (Somatic) Mutation' is not present at birth, but is acquired sometime later. Acquired mutations are much more common and most cancers are caused by them. This Somatic Mutation Theory (SMT) has become the dominant paradigm. ${ }^{5}$

Per Somatic Mutation Theory, a multistep process - initiation, promotion and progression - of random mutations in some key genes leads to cancer. These key genes are either oncogenes or tumor suppressor genes.

An oncogene results from mutation of proto-oncogenes. The latter are healthy normal genes that help cells grow. The bad oncogene can become permanently activated causing cells to grow out of control. Too many copies of a proto-oncogene are also called 'oncogene'.

Tumor suppressor genes are normal genes that slow down cell division, repair DNA mistakes, or tell cells when to die (apoptosis). When these genes are mutated or defective, cells can grow out of control, which can lead to cancer. ${ }^{5}$ 
The sustained proliferative signaling leads to nuclear genomic instability, which underlies various hallmarks of cancer.

(There are further elaborations of this model with epigenetic alterations, classification of mutations as drivers and passengers -- discussed elsewhere in the article.)

\subsection{Core deficiencies of genetic theory of cancer}

\subsubsection{Carcinogens relegated to the side}

Only 5 to $10 \%$ of all cancers are attributable to genetic defects. The remaining $90-95 \%$ have their roots in the environment and lifestyle. ${ }^{6}$

In other words, most cancers are caused by chemical carcinogens, be they in tobacco products, food additives, pesticides, or environmental pollutants. But genetic theory of cancer minimizes their significance. Cancer risk is discussed in terms of importance of genes: high-penetrance, moderate-penetrance and low-penetrance. ${ }^{7}$ In the least important last group are two kinds of genes: DNA-repair and xenobiotic metabolizing genes..$^{8,9}$ The word 'xenobiotic' means 'foreign to the body' - and only under this category carcinogens are mentioned, almost as an afterthought.

Chemical carcinogens are, of course, foreign to the body but they must be put front-and-center when we are trying to understand cancer.

\subsubsection{No mechanism for selective mutations}

In our body, exogenous chemicals go through one or more metabolic pathways - majority mediated by the versatile cytochrome P450 enzymes - which may result in excretable compounds, or produce metabolites that are reactive and toxic. ${ }^{10}$ In case of asbestos particles and metal ions like Cadmium, reactive oxygen species (ROS) are produced. ${ }^{11,12}$ How can these myriad reactive molecules selectively attack only those genes which are involved in cell duplication (chromosome segregation, mitosis, cytokinesis), DNA repair or cell death (apoptosis)? Such genes are a small minority - less than $10 \%$ - of the genome, ${ }^{13-16}$ and from the perspective of these relatively tiny chemical compounds, the DNA strand of one gene is no different than that of any other gene. (The carcinogens are usually not known to cause other kinds of genetic damage to the cell, which would indicate genome-wide assault.) No mechanism is provided by which carcinogens, or their metabolic products - or old age - might impair only those protein-coding genes - superset of proto-oncogenes and tumor suppressor genes - which are involved in cell division, DNA repair and apoptosis.

\subsubsection{Immediate cause of unrestrained cell growth unknown}

Even if we ascribe carcinogens-or-their-transformed-products some mysterious power to locate the relevant proto-oncogenes to damage them - or attribute such damage to age-related or random deteriorations - how could these point mutations trigger uncontrolled cell growth? Normally, a defect in an entity results in its not functioning at all or functioning at a reduced level. (That is what happens when 'tumor suppressor genes' are mutated; it is worth noting that only one such non-functional/missing gene, RB1, is known to directly cause cancer in the 
extremely rare case of retinoblastoma.) Despite decades of intensive hunt, no cancer-causing gene or genes (oncogenes) have been identified which are necessary-and-sufficient to cause cancer.

In the last two decades, modifications in epigenetic regulators like $\mathrm{CpG}$ island methylation, histone acetylation and miRNA-associated silencing have been introduced as possible pathways in tumorigenesis. ${ }^{17}$ The mechanisms of such alterations do seemingly account for role of xenobiotics in our environment. ${ }^{18}$ However, the immediate cause of uncontrolled cell proliferation remains as elusive as ever.

In brief, the gene-based theory of cancer fails to answer some basic questions about the process of carcinogenesis. The raison d'être for the concept of 'oncogenes' is correlation or the presence of mutated genes at the site of cancerous growth. Could these mutated genes be endproducts of malignant growth, just as dead and wounded soldiers are seen at the end of a war. Even healthy soldiers do not cause war since they are simply following orders from higher-ups. Could genes be no different, merely responding to biochemical signals or cues?

The next two sections evaluate in detail evidence for the role of genes in causing inherited and non-inherited cancers.

\subsection{In hereditary and familial cancers, few oncogenes identified}

Having certain inherited genetic mutations may increase a person's risk of developing cancer, but it does not necessarily mean that person will get cancer. Such medical conditions are usually called "syndromes". The most common Hereditary Cancer Susceptibility Syndromes are Lynch Syndrome, Li-Fraumeni Syndrome, Von Hippel-Lindau Syndrome, Familial Adenomatous Polyposis (FAP) and Cowden Syndrome. The cancer risk can be passed from generation to generation in a family, though some de novo mutations are also seen without family history. They all follow an autosomal dominant inheritance pattern, so that a single copy of the specific mutation is enough to predispose a person to the disease. ${ }^{19,20}$

In all these syndromes, tumor suppressor genes in germline mutations are culprit. ${ }^{21}$

Tumor suppressor genes (BRCA1 and BRCA2) are also implicated in familial breast and ovarian cancers. They increase susceptibility to cancers and are passed down through a family in an autosomal dominant manner. Only 5-10\% of breast cancer fall in this "hereditary" category; most such cancers occur sporadically in people with no family history. ${ }^{21}$

A tumor suppressor gene is also involved in the Retinoblastoma, which is a historic case. The mutation/deletion in its RB1 gene was the earliest one identified, in 1971, and gave a boost to gene-based view of cancer. ${ }^{22}$ This childhood disease is unique and not called a syndrome since non-functional RB1 gene does not simply predispose but directly causes cancer of retina, though some epigenetic changes may be needed. Only about 1 out of 3 cases are due to germline mutation, usually acquired during early development in the womb, rarely inherited from a parent. Majority of retinoblastomas are non-congenital and develop in only one eye. ${ }^{20,21}$ 
On the other hand, mutations in the proto-oncogenes have been identified in only two types of such cancers: RET and MYCN/ALK genes in Multiple Endocrine Neoplasia type 2 (MEN2) and neuroblastoma, respectively. The former is a germline mutation, linked to a high lifetime risk of developing medullary thyroid cancer, but some sporadic mutations are needed for onset of disease. ${ }^{21,23}$ The latter is cancer of the nerve cells of mainly children, but family history of the

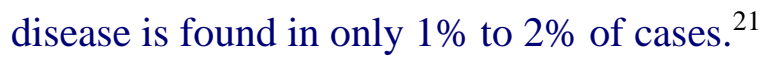

Thus in cancers with hereditary components, time and again, the genes associated are tumor suppressor genes. Only rarely do we find proto-oncogenes, and when we do, some external non-inherited factors are involved in turning them into bad cancer-causing oncogenes. (In the next section, oncogenes are discussed in detail.)

\subsection{In somatic cancers, many oncogenes, but no clear causative role}

Despite extensive search, over the last many decades, for proliferation-inducing 'oncogenes' and mutated 'tumor suppressor genes', no meaningful pattern has emerged for any type of noninherited (somatic) cancer.

Findings show many inconsistencies. ${ }^{24}$ For example:

- The same tumor may contain many distinct foci, with different subpopulation of mutations in each. ${ }^{25}$

- Mutations may vary dramatically from one stage of tumor progression to another. ${ }^{26}$

- Metastasized tumors often have different mutations than primary tumor. ${ }^{27}$

- For the same type of cancer, mutated genes are often different and random, for different individual. ${ }^{26}$

- Presence of mutations differ from country to country. In non-small cell lung cancer tumors, mutations found in 15 out of 58 Japanese patients were there in only 1 out of 61 US patients with the same cancer. ${ }^{28}$

Thus mutated genes in a tumor are varied and random at all levels, making any functional and causal interpretation very difficult. As if every cancer cell is a unique experiment in nature, having its own mutational signature, reflective of its distinct lineage history within the evolving neoplasm. ${ }^{29}$

Unsurprisingly, the majority of representative "high-quality" cancer research papers are unrepeatable. Scientists at Amgen were able to reproduce findings in only 6 (11\%) of 53 such published papers. ${ }^{30}$

\subsubsection{The Cancer Genome Atlas Program}

In 2006, a landmark cancer genomics program, The Cancer Genome Atlas (TCGA), was launched by NCI, sequencing over 20,000 primary cancers spanning 33 cancer types. ${ }^{31}$

The aim of the program was to provide sufficient data so that some knowledge gaps are filled and the landscape of cancer genetics becomes comprehensible. However no such thing happened. No recognizable patterns emerged. No synergistic accounts could be provided. Observed genetic mutations are still heterogeneous or diverse and still random and complex. We 
do have an ever increasing collection of genetic changes associated with cancer, that need cataloging. ${ }^{26,32,33}$

The enormous data has not yielded any specific gene mutation - or any combination of mutations - that is necessary, let alone sufficient, to initiate the transition from one to another stage of malignant neoplastic progression. A considerable disconnect is seen between nominal "oncogenic mutation" and cancer phenotype. ${ }^{34}$

There is a sense that accumulated data is overwhelming researchers' abilities of interpretation. ${ }^{29}$ However, a small effort is made by putting all the mutations in two lots: drivers and passengers. Former are causal, while the latter are there by chance. Such ad hoc elaborations have been seen, by some critics, akin to the use of epicycles in pre-Copernican astronomy. ${ }^{35}$ The futility of the latest elaboration becomes obvious when driver mutations are found in benign and premalignant conditions, occasionally at higher frequencies than in their malignant counterparts. ${ }^{36}$ The concept of cancer-inducing 'oncogene' is looking more and more like a phantom - and SMT no more than an epiphenomenon. A new paradigm is called for. ${ }^{37}$

\subsection{Epidemiological evidence against genetic basis of cancer}

Cancer genetics explains the increase in human cancers in post-industrial societies by pointing to significant lengthening of lifespan. It posits that the age-related molecular and physiological deteriorations may act in concert to promote cancer. The combined pathogenetic effects of accumulated mutations, increased epigenetic dysregulation, telomere dysfunction, reduced DNA repair capacity and altered stromal milieu - all take their toll. ${ }^{38}$ In short, per gene-based view, cancer is largely a disease of old age.

But epidemiological studies often undermine this assertion. An editorial in New England Journal of Medicine stated: "Geographic differences, trends over time in the risk of cancer, and detailed studies of migrant populations overwhelmingly implicate environmental exposures as major causal factors and often identify the responsible carcinogens (e.g., tobacco, alcohol, radiation, occupational toxins, infections, diet, drugs). From this work has come the widely accepted estimate that 80 to 90 percent of human cancer is due to environmental factors". 39

Analysis of data of childhood cancers from 19 European countries showed an annual increase of $2 \%$ in infant cancer over the period 1978-1997. Incidence rates of many, but not all, cancers in children and adolescents were rising. ${ }^{40}$

Similarly, an epidemiological study, funded by NIC, alarmingly found that the incidence of cancer in the ' 15 to 29 year' age group increased steadily between 1975-2000. ${ }^{41}$

A very recently published study has estimated the cancer burden attributable to 13 occupational carcinogens across 195 countries in years 1990-2017. It found that, except for the most advanced countries (top $1 / 5^{\text {th }}$ ), cancer deaths were higher in '50 to 69 years' age group compared to 'older than 70 years' group; people in ages ' 15 to 49 years' also died from cancer. ${ }^{42}$

Such findings cannot be reconciled with the view that cancer is essentially a disease of old age.

\subsubsection{Epidemiology gold standard - study of twins}


Studies of monozygotic (identical) and dizygotic twins are unsurpassed in distinguishing genetic from environmental traits.

A study published in Lancet reported that if one member of a pair of identical twins develops acute leukemia in childhood, the chances of leukemia in the other twin are no higher than $20 \%$. The concordance decreases with increasing age of onset of leukemia, being highest during the first year of life and low after 7 years of age. ${ }^{43}$

Among 432 sets of twins, when at least one was affected by Hodgkin's disease, none of the 187 pairs of dizygotic twins became concordant for Hodgkin's disease, and only 10 of the 179 pairs of monozygotic twins did. ${ }^{44}$

The data on 44,788 pairs of twins in Sweden, Denmark and Finland showed that inherited genetic factors make a minor contribution to susceptibility to most types of cancers. The environment had the principal role in causing sporadic cancer. ${ }^{45}$

Such studies contradict the view that genes play a preeminent role in incidences of cancer.

\section{Source of carcinogenesis maybe outside nucleus, away from genes}

As early as 1975, it was reported that the carcinoma cells, after introduction into normal blastocysts, can give rise to a large variety of normal tissues - mostly strikingly, sperms - in mosaic mice, thereby showing that tumorigenesis may not involve damage to the genes, but only aberrations of gene expression. ${ }^{46}$

In 1987 a study showed that when cells are reconstituted by fusing karyoplasts from malignant cells with cytoplast of normal cells, the tumorigenic phenotype was extinguished. ${ }^{47}$ The next year, in 1988, same authors reported that in cells derived by fusion of cytoplasts from malignant cells with karyoplasts of normal cells, tumors were seen in $97 \%$ of the animals injected. ${ }^{48}$ The Figure 1 is visual depiction of their findings:
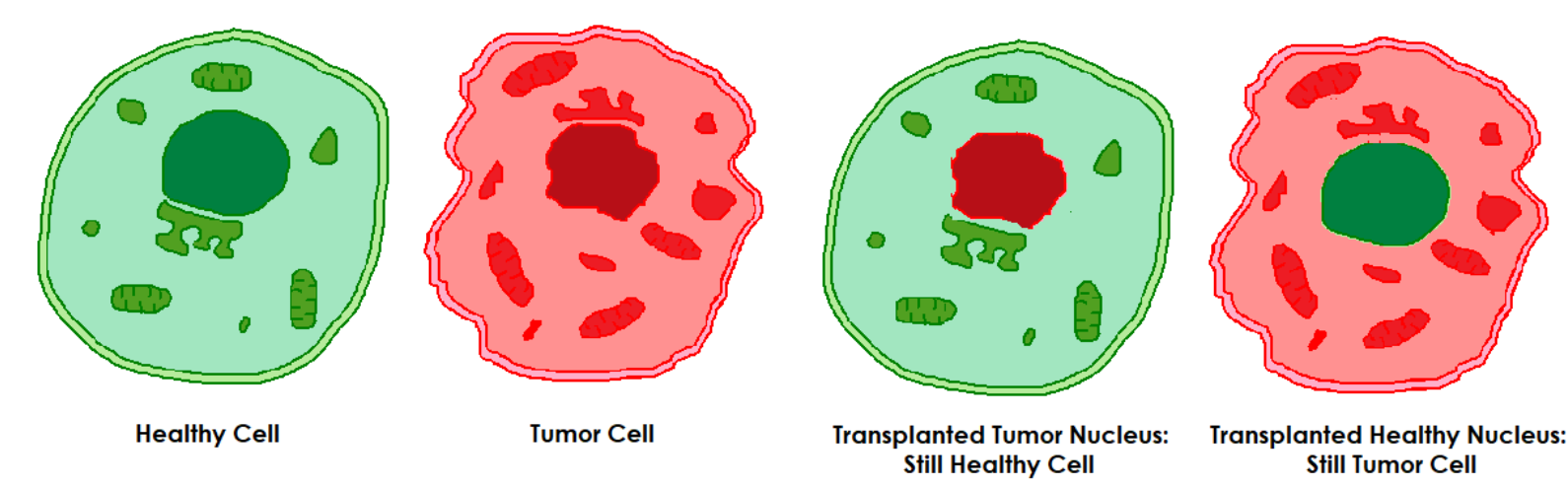

Figure 1: Transplanted Nucleus (and genes within) do not hold key to Tumorigenesis

At the end of that 1988 article, one can see:

EDITOR'S STATEMENT

This is the first description of cytoplasmic mediation of tumorigenesis. There is a clear indication that cytoplasmic elements play a role in the expression of the malignant phenotype. 
This addendum by the editor of that journal was very out-of-ordinary, and for good reason. It was a very clear demonstration that genes may play little or no role in carcinogenesis - contrary to the prevailing view of cancer as a genetic disease. Even after 33 years, such evidence is being ignored. It is hard to shake the belief of the vast majority of cancer researchers who cannot take their eyes off the genes. ${ }^{49}$

Subsequent researchers have confirmed the phenomenon. For example, in 2003, it was reported that blastocysts derived from medulloblastoma nuclei form embryos with typical cell layers, showing normal patterns of tissue differentiation. ${ }^{50}$ Interestingly, these results were interpreted as "epigenetics reprogramming abrogating tumorigenic phenotype", which is a stretch since even the most ardent proponents of 'epigenetics model of carcinogenesis' state that genetic mutations are secondary "critical by-products", not absent. ${ }^{17}$ How could transfer of nuclei make those genetic mutations go away?

A more plausible explanation was hinted at earlier: the root of cancer may not be malfunctioning genes, but some biochemical processes in cytoplasm which may be triggering unrestricted cell growth. The remainder of the article will delve into the biochemistry of cancer.

\subsection{Looking for origin of cancer in cytoplasm's biochemical activities}

Due to conceptual limitations of the cancer gene mutation theory, and accumulated evidence against it - as described in the previous sections - researchers have started looking outside the nucleus in attempts to unravel the secrets of cancer.

In recent years, most attention has been paid to mitochondria. A century-old Warburg Hypothesis has been revived which posits that mitochondrial dysfunction is the root cause of cancer, resulting in glucose fermentation even when enough oxygen is present. In the updated version, a plethora of random somatic mutations in tumors are seen as downstream effects of insufficient respiration with compensatory fermentation. ${ }^{51}$ Examples of powerful mutagens like ROS (reactive oxygen species) are given which are produced in damaged mitochondria.

Unfortunately, mitochondria-based carcinogenesis theory has one serious inadequacy. It cannot explain why do cells start multiplying out of control when mitochondria malfunction? In other words, it is as helpless as the genetic theory in explaining the immediate cause of cancer.

$*$

Among those who are frustrated at the glacial pace of progress on the cancer-front is one of the fathers of molecular biology, Dr. James Watson, who spent 3 decades exploring genetic aspects of cancer as director of Cold Spring Harbor Laboratory, NY. On May 12, 2016 in New York Times, he stated:

...locating the genes that cause cancer has been "remarkably unhelpful" - the belief that sequencing your DNA is going to extend your life is "a cruel illusion". If he were going into cancer research today, he would study biochemistry rather than molecular biology. ${ }^{52}$ 
To look for mechanisms of cancer-causation in biochemistry is far from counter-intuitive. After all, most cancers are caused by toxic chemicals and the earliest drugs designed to treat cancer, just after WW2, were based on the knowledge of biochemistry. ${ }^{53}$ Most chemotherapeutic drugs, synthesized ever since, often target some biochemical pathway implicated in cancer.

To fully understand the biochemistry of cancer, we must look at the activity of various enzymes involved in cancerous proliferation, since virtually nothing takes place in a biological cell without mediation by one or more enzymes.

\subsection{Pivotal enzyme in cancer growth may demystify cancer}

Ribonucleotide Reductase (RnR) enzyme converts the building blocks of RNA into the building blocks of DNA. Beside catalyzing the de novo production of DNA precursors, RnR is also involved in DNA repair. It is the rate-limiting enzyme for DNA synthesis, without which no cell can replicate, no cancer can grow. ${ }^{54}$

Activities of prominent enzymes in healthy and cancerous tissues are compared in Table 1. In a growing tumor, activity of the enzyme Ribonucleotide Reductase jumps up exponentially, much more than that any other enzyme - almost $8 x$ more than even DNA polymerase. ${ }^{55}$ 
Table 1 (taken from Weber G. Biochemical strategy of cancer cells and the design of chemotherapy. Cancer Res. 1983; 43, 3466-3492.)

\begin{tabular}{|c|c|c|c|}
\hline \multicolumn{4}{|c|}{$\begin{array}{l}\text { Table } 1 \\
\text { Comparison of activities of pyrimidine-and DNA-synthetic and -catabolic enzymes } \\
\text { in liver and in rapidly growing hepatoma } \\
\text { Data are expressed as specific activity and as percentages of the normal liver } \\
\text { values. In calculations, the values } 200 \mathrm{mg} \text { of protein per } \mathrm{g} \text {, wet weight, of tissue } \\
\text { for homogenates and } 80 \mathrm{mg} \text { of protein per } \mathrm{g} \text { for supernatant fluids were used. } \\
\text { Enzymic activities were those determined in this laboratory and in other centers. }\end{array}$} \\
\hline Enzymes & EC no. & $\begin{array}{l}\text { Normal liver } \\
\text { (pmol/hr/mg } \\
\text { protein) }\end{array}$ & $\begin{array}{l}\text { Rapidly } \\
\text { growing } \\
\text { hepatoma } \\
3683 F(\% \\
\text { of liver) }\end{array}$ \\
\hline \multicolumn{4}{|l|}{ Anabolic enzymes } \\
\hline $\begin{array}{l}\text { Ribonucleotide reductase } \\
\text { DNA polymerase } \\
\text { dTMP synthase } \\
\text { dTMP kinase } \\
\text { Deoxycytidine kinase } \\
\text { Thymidine kinase } \\
\text { CTP synthetase } \\
\text { Carbamoyl-phosphate synthe- } \\
\text { tase II }\end{array}$ & $\begin{array}{l}1.17 .4 .1 \\
2.7 .7 .7 \\
2.1 .1 .6 \\
2.7 .4 .9 \\
2.7 .1 .74 \\
2.7 .1 .21 \\
6.3 .4 .2 \\
2.7 .2 .9\end{array}$ & $\begin{array}{r}23 \\
56 \\
180 \\
420 \\
800 \\
900 \\
5,500 \\
10,000\end{array}$ & $\begin{array}{r}18,348 \\
5,806 \\
2,860 \\
7,000 \\
1,400 \\
3,920 \\
1,122 \\
950\end{array}$ \\
\hline $\begin{array}{l}\text { dCMP deaminase } \\
\text { Uracil phosphoribosyltransferase } \\
\text { Ornithine-5'-monophosphate } \\
\text { decarboxylase }\end{array}$ & $\begin{array}{l}2.4 .2 .9 \\
4.1 .1 .23\end{array}$ & $\begin{array}{l}12,000 \\
19,000 \\
34,000\end{array}$ & $\begin{array}{l}750 \\
760 \\
889\end{array}$ \\
\hline $\begin{array}{l}\text { Orotate phosphoribosyltransfer- } \\
\text { ase }\end{array}$ & 2.4.2.10 & 47,000 & 599 \\
\hline $\begin{array}{l}\text { Uridine phosphorylase } \\
\text { Uridine-cytidine kinase } \\
\text { Dihydroorotase } \\
\text { Aspartate carbamoyltransferase } \\
\text { UDP kinase }\end{array}$ & $\begin{array}{l}2.4 .2 .3 \\
2.7 .1 .48 \\
3.5 .2 .3 \\
2.1 .3 .2 \\
2.7 .4 .6\end{array}$ & $\begin{array}{r}164,000 \\
156,000 \\
246,000 \\
448,000 \\
444,000,000\end{array}$ & $\begin{array}{l}671 \\
694 \\
418 \\
706 \\
298\end{array}$ \\
\hline \multicolumn{4}{|l|}{ Catabolic enzymes } \\
\hline $\begin{array}{l}\text { Dihydrouraci dehydrogenase } \\
\beta \text {-Ureidopropionase } \\
\text { Thymidine phosphorylase } \\
\text { Dihydropyrimidinase }\end{array}$ & $\begin{array}{l}1.3 .1 .2 \\
3.5 .1 .6 \\
2.4 .2 .4 \\
3.5 .2 .2\end{array}$ & $\begin{array}{r}26,000 \\
144,000 \\
234,000 \\
276,000\end{array}$ & $\begin{array}{r}9 \\
31\end{array}$ \\
\hline
\end{tabular}

The enzyme RnR consists of two dissimilar subunits, proteins RRM1 and RRM2. Larger RRM1 is a dimer and binds substrates as well as allosteric effectors. Smaller RRM2 is also a dimer, and contains an essential tyrosyl free-radical which is stabilized by an adjacent oxo-bridged binuclear iron center. ${ }^{56}$

$$
\text { [Tyr-O•- - - } \left.\left(\mathrm{Fe}^{3+}-\mathrm{O}-\mathrm{Fe}^{3+}\right)\right]
$$

The levels and activity of RnR are tightly regulated via multi-layered mechanisms that involve intricate interplay between gene expression, cell cycle checkpoints, proteolysis, together with the allosteric effects via two allosteric sites, the specificity site (s-site) and the overall activity site (asite). ${ }^{54}$

Exquisite controls of RnR activity are necessary to optimally regulate cell multiplication. This critical enzyme for cell-division is already known to impact cancer susceptibility. ${ }^{57}$ The next small step needs to be taken to view this enzyme as the site where, in all probability, cancer is initiated. 
RnR-based model of carcinogenesis proposes that RRM2 subunit of this enzyme, containing diferric-tyrosyl-radical active site, is primary, and perhaps the only, target of all variety of carcinogenic chemicals. Various characteristics of tumor cells - anchorage independence, dedifferentiation, metastasis, angiogenesis, genetic aberrations, chromosomal anomalies, genomic instability, etc. - all result from the cascade of events that is initiated at the RRM2 subunit by adverse stimuli.

It is noteworthy that the RnR enzyme resides in the cytosol. The deoxynucleotides produced by it diffuse into the nucleus or are transported into mitochondria. ${ }^{58}$ Thus this model is in accordance with observations depicted in Figure 1.

The mechanism of initiation of cancer at the RRM2 subunit of the enzyme RnR in a variety of malignant neoplastic transformations is elucidated below: (First two sections are based on circumstantial evidence while direct experimental proof exists for the last two.)

3.2.1. Chemicals, thought to be culpable in a large number of cancer cases, fall in two broad categories of carcinogens: direct-acting and indirect-acting. The direct carcinogens, of which there are only a few, e.g., dimethyl sulfate, are reactive electrophiles, i.e., they seek out and react with negatively charged centers in other compounds. Indirect carcinogens such as highly inert polycyclic aromatic hydrocarbons, can attain even more reactive electrophilic centers by going through any of the various metabolic oxidative pathways in the body, involving powerful cytochrome P-450 enzymes. ${ }^{10}$

In addition to being/becoming electrophilic, chemical carcinogens are, in general, hydrophobic in nature. Molecules with these characteristics are especially suited to access the active site of the enzyme RnR since Glu/Asp residues around ferric ions constitute a negatively charged environment, ${ }^{56,59}$ and tyrosyl free-radical is located in a hydrophobic pocket. ${ }^{56,60}$

According to this model of the mechanism of induction of cancer, carcinogenic chemicals, and/or their metabolic products, are attracted to the electro-magnetically charged active site of the enzyme ribonucleotide reductase, and once there, would disturb the finely tuned rhythmic controls in place. Accumulation of such miscreant/irritant molecules may go on for years, till a threshold is crossed, resulting in persistent overstimulation. A chain of events is set in motion culminating in the production of outlaw tumor cells. Responding to the "non-self" antigens on the surface of these cells, the immune system would eliminate them. However, over a period of time ("the latency period"), weakly antigenic cancer cells, capable of evading immune surveillance, would evolve - and cancerous growth gains a foothold.

3.2.2. Extremely fine asbestos fibers are known to cause malignant tumor growth after a latency period of 20 to 40 years. After uptake by lung-cells, phagocytic cells that engulf asbestos fibers produce large amounts of free radicals and other reactive oxygen species (ROS) due to their inability to digest the fibers. This model provides for these oxygen radicals a singularly sensitive target-site to initiate, albeit unwarranted, cell proliferation - in a manner similar to carcinogenic chemicals. Slow struggle with the immune system would commence then on, which may be lost only after a few decades. Please note, epidemiological studies indicate that ironcontaining asbestos fibers appear more carcinogenic. ${ }^{11}$ The case of established carcinogenic 
metal ions like Cadmium is very similar since elevated levels of reactive oxygen species (ROS) are seen in the human body in their presence. ${ }^{12}$

3.2.3. High-risk human Papilloma viruses (HPVs) are causal agents for human cervical cancers. The viral proliferation activity is completely dependent on its two genes E6 and E7, the latter of which is more potent and induces upregulation of RRM2 subunit of the enzyme RnR of the host. ${ }^{61}$ The exogenous activation of RnR, which was initially meant to help make copies of only the invading virus, over time ("latency period") starts building unneeded copies of the cells of the human host.

In fact, diferric-tyrosyl-radical containing RRM2 has become a new molecular marker for the diagnosis and clinical outcomes of cervical cancer. ${ }^{62}$

3.2.4. While studying of mechanism of cancer causation by HPVs, researchers discovered that the E7 protein of virus targets and inactivates the retinoblastoma gene (RB). ${ }^{63}$ This results in the release of active E2F transcription factors which then bind to the RRM2 promoter region, putting enzyme RnR in overdrive - and causing improper proliferation of cells. ${ }^{61}$ These findings make it possible to understand why non-functional/missing RB gene in infants is responsible for retina cancer, mediated by unchecked activity of RnR.

Thus, we have seen that in all types of cancer, persistent over-stimulation/overexpression of the active-site-containing RRM2 subunit of the enzyme ribonucleotide reductase may be the trigger that sends the entire elegant cell-division machinery spinning out of control.

This RnR-based model of carcinogenesis answers the hitherto unanswerable questions about cancer: What is the immediate cause of unrestrained cell growth? How and why does cell proliferation go out of control?

\subsection{Disabling the enzyme ribonucleotide reductase will defeat cancer}

Whether or not cancer is initiated, in all cases, at the enzyme ribonucleotide reductase (RnR), it is beyond dispute that if you stop RnR, you stop cancer. As a result, this enzyme is considered a classical target for cancer therapeutics. ${ }^{64,65}$

Chemotherapeutic compounds aiming to block this enzyme have been synthesized since early 1970 's. ${ }^{66}$ They fall in three broad categories: iron chelators inhibitors, radical scavengers and nucleoside analogues. Unfortunately these drugs have limited potency and produce toxic side effects. Despite this, several U.S. Food and Drug Administration-approved RnR inhibitors are used clinically to treat various forms of cancer. ${ }^{57}$

The enzyme RnR remains key to stopping cancer. By blocking this enzyme, we would, most likely, be nipping cancer in the bud.

\section{Conflict of Interest Statement}

The author declares that there is no conflict of interest. 


\section{Acknowledgments}

The author wishes to thanks Dr. Barry Kendler of University of Bridgeport, Connecticut for his help in early stages of manuscript preparation.

\section{REFERENCES:}

(1) Pollack A: Huge Genome Project Is Proposed to Fight Cancer, NYTimes - March 28, 2005, Section A, Page 1. https://www.nytimes.com/2005/03/28/health/huge-genome-project-is-proposed-to-fightcancer.html?searchResultPosition=2 (retrieved on May 28, 2021)

(2) Cancer World 2013, Dr. James Watson https://archive.cancerworld.net/cover-story/jim-watson-dna-revealed-the-causes-it-maynever-reveal-a-cure/ (retrieved on May 28, 2021)

(3) Howlader N, Noone AM, Krapcho M, et al. (eds). SEER Cancer Statistics Review, 19752017, National Cancer Institute. Bethesda, MD https://seer.cancer.gov/csr/1975_2017/ (retrieved on May 28, 2021)

(4) Beardsley T. "A War not Won" in Scientific American 270, 1, 130-138 (January 1994) https://doi.org/10.1038/scientificamerican0194-130

(5) Information taken from the website of American Cancer Society https:/cancer.org (retrieved in May 2021)

(6) Anand P, Kunnumakkara AB, Sundaram C, et al. Cancer is a preventable disease that requires major lifestyle changes. Pharm Res. 2008; 25:2097-2116. https://doi.org/10.1007/s11095-008-9661-9

(7) Shiovitz S, Korde LA. Genetics of breast cancer: a topic in evolution Ann Oncol. 2015 Jul; 26(7):1291-1299. https://doi.org/10.1093/annonc/mdv022

(8) Garte S. "Chapter 5. Individual Susceptibility and Gene-Environment Interaction". In Chris Wild, Paolo Vineis, Seymour Garte (ed.). Molecular Epidemiology of Chronic Diseases. John Wiley \& Sons. (2008) pp. 55-69. Print ISBN: 9780470027431. https://doi.org/10.1002/9780470725726.ch5

(9) Sasiadek M, Karpinski P. Genetic Theory of Cancer. Short Review. Pol J Surg. 2009; 81(10) :478-485. https://www.researchgate.net/publication/244937161_Genetic_Theory_of_Cancer_Short_Review

(10) Raunio H, Kuusisto M, Juvonen RO et al. Modeling of interactions between xenobiotics and cytochrome P450 (CYP) enzymes. Front. Pharmacol. 2015; 6 :123. https://doi.org/10.3389/fphar.2015.00123 
(11) Toyokuni S. Mechanisms of asbestos-induced carcinogenesis. Nagoya J Med Sci. 2009 Feb; 71(1-2) :1-10. https://pubmed.ncbi.nlm.nih.gov/19358470/

(12) Hartwig A. "Chapter 15. Cadmium and cancer". In Astrid Sigel, Helmut Sigel, Roland K. O. Sigel (ed.). Cadmium: From Toxicology to Essentiality. Metal Ions in Life Sciences. 11. Springer. (2013) pp. 491-507.

https://pubmed.ncbi.nlm.nih.gov/23430782/

(13) Tsutsumi M, Kowa-Sugiyama H, Bolor H, et al. Screening of genes involved in chromosome segregation during meiosis I: in vitro gene transfer to mouse fetal oocytes. $\mathrm{J}$ Hum Genet. 2012 Aug; 57(8):515-22. https://doi.org/10.1038/jhg.2012.61

(14) Kittler R, Pelletier L, Heninger AK, et al. Genome-scale RNAi profiling of cell division in human tissue culture cells. Nat. Cell Biol. 2007; 9 :1401-1412 https://doi.org/10.1038/ncb1659

(15) Wood RD, Mitchell M, Lindahl T. Human DNA repair genes. Mutation research. 2005; 577(1-2) :275-83. https://doi.org/10.1016/j.mrfmmm.2005.03.007

(16) Holleman A, den Boer ML, de Menezes RX, et al. The expression of 70 apoptosis genes in relation to lineage, genetic subtype, cellular drug resistance, and outcome in childhood acute lymphoblastic leukemia. Blood. 2006; 107(2):769-776. https://doi.org/10.1182/blood-2005-07-2930

(17) Burgio E, Migliore L. Towards a systemic paradigm in carcinogenesis: linking epigenetics and genetics. Mol Biol Rep. 2015; 42 :777-790.

https://doi.org/10.1007/s11033-014-3804-3

(18) Tamási V, Monostory K, Prough RA, et al. Role of xenobiotic metabolism in cancer: involvement of transcriptional and miRNA regulation of P450s. Cell. Mol. Life Sci. 2011; 68:1131-1146. https://doi.org/10.1007/s00018-010-0600-7

(19) Peltomäki P. Lynch syndrome genes. Fam Cancer. 2005; 4(3) :227-32 https://doi.org/10.1007/s10689-004-7993-0

(20) Davidoff AM. Pediatric oncology. Semin Pediatr Surg. 2010; 19(3) :225-233. https://doi.org/10.1053/j.sempedsurg.2010.03.007

(21) Information taken from cancer.net - website of American Society of Clinical Oncology, and cancer.org - website of American Cancer Society, retrieved on May 28, 2021.

(22) Knudson A. Mutation and cancer: statistical study of retinoblastoma. Proc Natl Acad Sci USA. 1971; $68: 820-823$. https://doi.org/10.1073/pnas.68.4.820 
(23) Information obtained from the website of Stanford Medical Center. Retrieved on May 28, 2021.

https://stanfordhealthcare.org/medical-conditions/cancer/multiple-endocrine-neoplasia.html

(24) Miklos GLG. The Human Cancer Genome Project - one more misstep in the war on cancer. Nat Biotechnol. 2005; 23 :535-537.

https://doi.org/10.1038/nbt0505-535

(25) Masters JRW, Lakhani SR. How diagnosis with microarrays can help cancer patients Nature. 2000; 404:921

https://doi.org/10.1038/35010139

(26) Salk JJ, Fox EJ, Loeb LA. Mutational heterogeneity in human cancers: origin and consequences. Annu Rev Pathol. 2010; 5 :51-75.

https://doi.org/10.1146/annurev-pathol-121808-102113

(27) Wu JM, Fackler MJ, Halushka MK, et al. Heterogeneity of breast cancer metastases: comparison of therapeutic target expression and promoter methylation between primary tumors and their multifocal metastases. Clin Cancer Res. 2008;14(7):1938-46. https://doi.org/10.1158/1078-0432.ccr-07-4082

(28) Paez JG, Jänne1 PA, Lee JC, et al. EGFR Mutations in Lung Cancer: Correlation with Clinical Response to Gefitinib Therapy. Science. 2004; 304:1497-1500. https://doi.org/10.1126/science.1099314

(29) Weinberg RA. Coming Full Circle — From Endless Complexity to Simplicity and Back Again. Cell. 2014; 157(1):267-271. https://doi.org/10.1016/j.cell.2014.03.004

(30) Begley CG, Ellis LM. Drug development: Raise standards for preclinical cancer research. Nature. 2012; 483(7391): 531-533. https://doi.org/10.1038/483531a

(31) Nogrady B. How cancer genomics is transforming diagnosis and treatment. Nature. 2020; 579: S10-S11. https://doi.org/10.1038/d41586-020-00845-4

(32) Nicholson JM. Will we cure cancer by sequencing thousands of genomes?. Mol Cytogenet. 2013; 6:57. https://doi.org/10.1186/1755-8166-6-57

(33) Heng HH. The genomic landscape of cancers (Chapter 5) Beata Ujvari, Benjamin Roche, Frederic Thomas (Eds.), Ecology and Evolution of Cancer, Elsevier 2017; pp. 69-86 https://doi.org/10.1016/B978-0-12-804310-3.00005-3

(34) Brock A, Huang S. Precision Oncology: Between Vaguely Right and Precisely Wrong. Cancer Res. 2017; 77(23):6473-9. https://doi.org/10.1158/0008-5472.CAN-17-0448 
(35) Soto AM, Sonnenschein C. The somatic mutation theory of cancer: growing problems with the paradigm? BioEssays. 2004; 26:1097-1107.

https://doi.org/10.1002/bies.20087

(36) Kato S, Lippman SM, Flaherty KT, et al. The conundrum of genetic "drivers" in benign conditions, Journal of the National Cancer Institute. 2016; 108(8):djw036.

https://doi.org/10.1093/jnci/djw036

(37) Heng HH. Chapter 1 - From Mendelian Genetics to 4D Genomics. Genome Chaos, Academic Press, 2019, Pages 1-52.

https://doi.org/10.1016/B978-0-12-813635-5.00001-X

(38) DePinho RA. The age of cancer. Nature. 2000; 408:248-254

https://doi.org/10.1038/35041694

(39) Hoover RN. Cancer — Nature, Nurture, or Both. N Engl J Med. 2000; 343:135-136. https://doi.org/10.1056/NEJM200007133430210

(40) Pritchard-Jones K, Kaatsch P, Steliarova-Foucher E, et al. Cancer in children and adolescents in Europe. Eur J Cancer. 2006; 42:2183-2190.

https://doi.org/10.1016/j.ejca.2006.06.006

(41) Bleyer A, O'Leary M, Barr R, et al. (eds) (2006) Cancer epidemiology in older adolescents and young adults 15-29 years of age, including SEER incidence and survival: 1975-2000. NIH Pub. No. 06-5767. National Cancer Institute, Bethesda (MD) https://seer.cancer.gov/archive/publications/aya/aya_mono_complete.pdf

(42) Li N, Zhai Z, Zheng Y, et al. Association of 13 Occupational Carcinogens in Patients with Cancer, Individually and Collectively, 1990-2017 JAMA Netw Open. 2021 Feb 1; 4(2):e2037530.

https://doi.org/10.1001/jamanetworkopen.2020.37530

(43) Clarkson B, Boyse EA. Possible explanation of the high concordance for acute leukaemia in monozygotic twins Lancet. 1971; 7701:699-701

https://www.sciencedirect.com/science/article/pii/S014067367192705X/pdfft?md5=409fd98f $\underline{855 \mathrm{e} 16 \mathrm{~d} 2 \mathrm{f} 54 \mathrm{fcf} 888 \mathrm{f} 338 \mathrm{e} 5 \mathrm{a} \& \mathrm{pid}=1 \text {-s2.0-S014067367192705X-main.pdf }}$

(44) Mack TM, Cozen W, Shibata DK, et al. Concordance for Hodgkin's disease in identical twins suggesting genetic susceptibility to the young-adult form of the disease. N Engl J Med. 1995; 332(7):413-419. https://doi.org/10.1056/NEJM199502163320701

(45) Lichtenstein P, Holm NV, Verkasalo PK, et al. Environmental and heritable factors in the causation of cancer: Analyses of cohorts of twins from Sweden, Denmark, and Finland. N Engl J Med. 2000; 343(2):78-85. https://doi.org/10.1056/nejm200007133430201 
(46) Mintz B, Illmensee K. Normal genetically mosaic mice produced from malignant teratocarcinoma cells. Proc. Natl. Acad. Sci. U.S.A. 1975; 72(9):3585-3589. https://doi.org/10.1073/pnas.72.9.3585

(47) Israel BA, Schaeffer WI. Cytoplasmic suppression of malignancy. In Vitro Cell. Dev. Biol. 1987; 23:627-632. https://doi.org/10.1007/BF02621071

(48) Israel BA, Schaeffer WI. Cytoplasmic mediation of malignancy. In Vitro Cell. Dev. Biol. 1988; 24:487-490. https://doi.org/10.1007/BF02628504

(49) Joyner MJ, Paneth N, Ioannidis JP. What happens when underperforming big ideas in research become entrenched?. Journal of the American Medical Association. 2016; 316(13): 1355-1356. https://doi.org/10.1001/jama.2016.11076

(50) Li L, Connelly MC, Wetmore C, et al. Mouse embryos cloned from brain tumors. Cancer Res. 2003; 63(11):2733-6. https://cancerres.aacrjournals.org/content/63/11/2733

(51) Seyfried TN. Cancer as a mitochondrial metabolic disease. Front. Cell Dev. Biol. 2015; 3:43. https://doi.org/10.3389/fcell.2015.00043

(52) Apple S: An Old Idea, Revived: Starve Cancer to Death. New York Times. Page 64 of the Sunday Magazine. 12 $2^{\text {th }}$ May 2016. https://www.nytimes.com/2016/05/15/magazine/warburg-effect-an-old-idea-revived-starvecancer-to-death.html (retrieved on May 28, 2021)

(53) Farber S, Diamond LK, Mercer RD, et al. Temporary remissions in acute leukemia in children produced by folic acid antagonist, 4-Aminopteroyl-glutamic acid. N Engl J Med. 1948; 238(23):787-93. https://doi.org/10.1056/nejm194806032382301

(54) Nordlund P, Reichard P. Ribonucleotide reductases. Ann Rev Biochem. 2006; 75:681706.

https://doi.org/10.1146/annurev.biochem.75.103004.142443

(55) Weber G. Biochemical strategy of cancer cells and the design of chemotherapy. Cancer Res. 1983; 43:3466-3492.

https://pubmed.ncbi.nlm.nih.gov/6305486/

(56) Nordlund P, Sjöberg B-M, Eklund H. Three-dimensional structure of the free radical protein of ribonucleotide reductase. Nature 1990; 345:593-598.

https://doi.org/10.1038/345593a0 
(57) Aye Y, Li M, Long MJC, et al. Ribonucleotide reductase and cancer: biological mechanisms and targeted therapies. Oncogene. 2015; 34:2011-2021. https://doi.org/10.1038/onc.2014.155

(58) Pontarin G, Fijolek A, Pizzo P, et al. Ribonucleotide reduction is a cytosolic process in mammalian cells independently of DNA damage. Proc Natl Acad Sci USA 2008; 105(46):17801-17806 https://doi.org/10.1073/pnas.0808198105

(59) Strand KR, Karlsen S, Kolberg M, et al. Crystal structural studies of changes in the native dinuclear iron center of ribonucleotide reductase protein R2 from mouse 2004; J Biol Chem. 279:46794 http://dx.doi.org/10.1074/jbc.M407346200

(60) Liu A, Pötsch S, Davydov A, et al. The Tyrosyl Free Radical of Recombinant Ribonucleotide Reductase from Mycobacterium tuberculosis Is Located in a Rigid Hydrophobic Pocket. Biochemistry 1998; 37(46):16369-16377. https://doi.org/10.1021/bi981471p

(61) Wang N, Zhan T, Ke T, et al. Increased expression of RRM2 by human papillomavirus E7 oncoprotein promotes angiogenesis in cervical cancer. Br J Cancer. 2014; 110:1034-1044 https://doi.org/10.1038/bjc.2013.817

(62) Su Y-F, Wu T-F, Ko J-L, et al. The expression of ribonucleotide reductase M2 in the carcinogenesis of uterine cervix and its relationship with clinicopathological characteristics and prognosis of cancer patients. PLoS ONE. 2014; 9(3): e91644. https://doi.org/10.1371/journal.pone.0091644

(63) Huh KW, DeMasi J, Ogawa H, et al. Association of the human papillomavirus type 16 E7 oncoprotein with the 600-kDa retinoblastoma protein-associated factor, p600. Proc Natl Acad Sci USA. 2005; 102:11492-11497. https://doi.org/10.1073/pnas.0505337102

(64) Nuno SA, Cerqueira MFSA, Fernandes PA, et al. Ribonucleotide reductase: a critical enzyme for cancer chemotherapy and antiviral agents. recent patents on anti-cancer drug discovery. 2007; 2:11-29 https://doi.org/10.2174/157489207779561408

(65) Tessianna AM, Yi-Ting L, Michael EH, et al. Structure-guided design of anti-cancer ribonucleotide reductase inhibitors. Journal of Enzyme Inhibition and Medicinal Chemistry. 2019; 34(1): 438-450. https://doi.org/10.1080/14756366.2018.1545226

(66) Agrawal KC, Booth BA, Sartorelli AC. Potential antitumor agents. 7. 4'-diethyleneoxy derivatives of -(N)-heterocyclic carboxaldehyde thiosemicarbazones. Journal of Medicinal Chemistry. 1973; 16:715-7. https://doi.org/10.1021/jm00264a035 